\title{
Correction to: Intergenerational Coresidence and Mothers' Body Weight at Midlife
}

\author{
Zhe Zhang $^{1}$ (D) Corinne Reczek ${ }^{2} \cdot$ Cynthia G. Colen ${ }^{2}$
}

Published online: 19 March 2021

(c) Springer Nature B.V. 2021

\section{Correction to: Population Research and Policy Review (2020) 39:1051-1085 https://doi.org/10.1007/s11113-020-09567-x}

In the original publication of this article, the acknowledgement section has been missed to publish. Now the same has been provided in this correction.

Acknowledgement Support for this project was provided by the Ohio State University Institute for Population Research through a grant from the Eunice Kennedy Shriver National Institute for Child Health and Human Development of the National Institutes of Health, P2CHD058484.

Publisher's Note Springer Nature remains neutral with regard to jurisdictional claims in published maps and institutional affiliations.

The original article can be found online at https://doi.org/10.1007/s11113-020-09567-x.

\section{Zhe Zhang}

zz60@ rice.edu

1 Department of Sociology, Rice University, P.O. Box 1892, Houston, TX 77251-1892, USA

2 Department of Sociology, The Ohio State University, Columbus, USA 